\title{
Difference that matter: On love in the kennel of life
}

\author{
Cristina Pallí Monguilod \\ cristina_pallí@hotmail.com
}

Haraway, Donna (2003). The Companion Species Manifesto: Dogs, People, and Significant Otherness. Chicago: Prickly Paradigm Press.

About dogs? Well yes, indeed! Donna Haraway, amply known in feminist theory and technoscience studies, famous for her Cyborg Manifesto, published a book which, as the subtitle makes explicit, deals with dogs, humans and significant otherness. And not just any book of modest ambition, but nothing less than a second manifesto. To find the author of the stories on cyborg-transgressions, vampire-frankensteinian monstrosities and transgenic oncomice busy with 'dog writing' surprised all, amazed many, and disappointed some. Granted, the work is less surprising when one knows that human-animal relationships is a thriving topic in US academic landscape nowadays. Still, the unexpected work of the person who gathered collective enthusiasm around the figure of the cyborg provoked, above all, disorientation.

What is this astonishment due to? There can be no doubt that, on reading this book, we enter Haraway's universe; recognisable theoretically and methodologically, the tool-box is also known: figurations, partial connections, insistence upon the union of flesh-sign or fact-story, and, especially, the prominence of the notion of 'natureculture', that becomes a major theme in this book. Therefore, we can suppose that disorientation relates rather to the novel topic -the uncomfortable dogs. Opinions on the book are diverse. Some confess not to understand where the author is heading to, not quite knowing what to do with her proposals. Others question that this book contains a new proposal, different from previous works: what type of new liminal transgression is led by the dogs which cannot be proclaimed by hoisting the cyborg-flag? Others find these dog stories quite petty, and believe that only Haraway could afford a book like this. Many wonder whether there is 'something more' in these pages...

These reactions have not caught Haraway by surprise. In some conferences this springtime in Barcelona ${ }^{1}$, she herself ironically anticipated the possibility that readers think she's growing old -not finding a better theme that the pet with which she spends winter evenings in the sofa... She claimed to

\footnotetext{
${ }^{1}$ These conferences and seminars were organised by the Musueum of Contemporary Art in Barcelona (MACBA), with the collaboration of the Doctorate Programme of Social Psychology of the Universitat Autònoma de Barcelona (UAB) and the Centre for Women and Literature of the Universitat de Barcelona (UB). I also want to thank Helena Torres, who led a working group in these seminars, for her comments on a previous version of this paper.
} 
be aware that her new proposal was not as 'shinny' as her previous ones: no intelligent machines in the age of information society, neither biotechnological implants under the skin, not even sophisticated research on modest mice tidily confined in their experimental cages. Instead of all this, we find ourselves in woods, fields and gardens, inhabiting stories which mix the personal and the public, private loves with theoretical passions, and daily, apparently trivial worries with the search for political articulations. To be sure, for a particular audience this new work will have lost 'glamour': the peculiar and fruitful alliance between feminism and technoscience studies characteristic of Haraway's thought attracted some people who were initially more drawn to the bellicose, high-tech, science-fictional imagination of the cyborg, rather than to gender issues. Part of them don't quite know what to do now with mates as fleshy and slobbering as dogs.

However, judging from her naughty smile, Haraway seemed to rejoice at this circumstance, rather than regret it... Which should be enough to make us suspect that, under this innocent and banal appearance, these pages camouflage a more elaborated argument -plus, as it could not be otherwise, a provocation. One more, as usual in her, but this time not so much directed to fight scepticism as to challenge adherence. That Haraway talks to a convinced audience, familiar with her thought, can be conjectured from how she takes for granted, without many explanations, the concepts developed in her previous works ${ }^{2}$. The manifesto format does not offer an introduction or a conclusion out of which to clear a representative summary; since the argument takes shape and distributes throughout the whole book, a fast or partial reading will necessarily be insufficient. To appraise the suggestions and challenges the book poses, we will need a thorough analysis of her arguments.

Haraway has accompanied and defended her cyborg proposal before different publics, in different places, for years. Enough, we might assume, to arouse a certain feeling of surfeit; we should not forget that her slogan 'cyborgs for earthly survival' dates from 1985, more than 20 years ago! So it is hardly surprising that somebody with her intellectual trajectory feels restless and wants to change travelling mates -without disowning the old ones, so profitable in theoretical and political terms. On the contrary, to the Harawayan figurative stock, this book adds a new unexpected resource; amazing not for its exoticism or sophistication, but for its simple and common character. This new figuration, of which the dog is but a concretion, is called by Haraway "companion species", the main character of this new manifesto. Companion species, cum panis, species that share their bread ${ }^{3}$.

The term 'companion animal' -closer to that of 'pets', and that connects us with the technoscientific discourse of veterinary, with psychotherapeutical practices and with a blooming industry (p. 12-4)would be a subcategory of 'companion species'. If we take the example of the dog, we will see that its ontological diversity is not exhausted in being pets or companion animals; some also protect or herd livestock flocks, earn their bread as professional sportdogs or security guards, become military weapons, members of rescue teams or even police drug squads... Whereas pets are reputable

${ }^{2}$ For instance, Haraway, D (1991). Simian, Cyborgs, and Women. The Reinvention of Nature. London: Free Associations Books. Haraway, D. (1997). Modest_Witness@Second_Millennium. FemaleMan®_Meets_OncoMouse. London: Routledge.

${ }^{3}$ Haraway makes this etimology explicit in Haraway , D. (2006). 'A Note of a Sportswriter's Daughter: Companion Species'. For Helene Moglen (ed) Bodies in the making: Trangressions and Transformations. Santa Cruz, CA: New Pacific Press. 
companions, Haraway has something more radical in mind when she suggests this notion, and devotes the book to imply, more than define, what she means by it.

Companion species are those which accompany humans for centuries, crossing their history with ours, modelling it. This definition makes space for dogs and bitches, but also -the list is endless- for hens, bees, cereals and, for instance, bacteria living in our intestines, without which our survival would not be possible. For it is of live and survival we are talking here, and not of mere 'influences'. We do not simply live next to our companion species, but are in a relation of co-constitution with them. Following Whitehead and his important notion of prehension (p. 6-7), Haraway will defend that beings do not exist as independent entities, but only in relation; ontologically, we continue into each other, without clear boundaries limiting/defining entities previous to the relation. There are no subjects, objects, types, races, species or genders which are not a product of the relation (p. 7). On the contrary, to talk of companion species means to accept that who and what we are is always something relational, emergent, process-like, historical, mutable, specific, contingent, finite, complex, impure... In a strict sense, then, the major issue of the book is the relation, stating in a radical form that we cannot live without the others: "The relation is the smallest unit of analysis, and the relation is about significant otherness at every scale" (p. 24).

This is not a purely symbolic argument, because, as Haraway repeats in all her works, sign and flesh are inseparable. Contacts among species are not limited to communication, but also involve a mixture of genetic, chemical, virical and protein material, as well as life forms and economical practices, etc. It is difficult, for instance, to imagine a human genome which is not marked by molecular material from dogs, pigs, fowl and viruses (p. 31). We are constituted and live within each other in all our flesh, in relationships which comprise from beautiful solidarity to cruel violence. The trope 'metaplasm' ('a change in a word, for example by adding, omitting, inverting, or transposing its letters, syllables, or sounds' (p. 20)) is of use to Haraway to imagine this ontological remodelling product of the relation, to imagine how the flesh is remodelled in this co-existence among species. This is a co-existence which is constituted by layers of biology and history, exemplifying 'the implosion of nature and culture' in which live those species 'bonded in significant otherness' (p. 16). Indeed, there is an ontological exchange between species: companion species co-exist, co-habit and co-constitute each other in such an intimate way, that Haraway even speaks of kinship, clarifying that in this heterogeneous family the cyborgs would be the 'junior siblings' (p. 11).

To show these metaplasmatic relationships, Haraway works with our canine companions using her usual strategy: telling stories. Stories which narrate and constitute facts, and assemble new codevelopmental narrations that admit to this complex and collective mutual constitution among companion species, to this 'embodied cross-species sociality' (p. 4). Stories that question those anthropocentric stories which insist on dividing the course of time into (biologic) evolution for some entities on the one hand, and (social) history for others, deepening the big divide between nature and culture. Stories of natureculture that acknowledge the intimacies, mixtures and violences which inform and limit us. Stories which we must actively inhabit so as to tell the truth about relationship (p. 20), so that they can become a collective resource to imagine other relational practices.

This is why, along one hundred pages, Haraway displays stories about the co-evolution of dogs and humans during centuries, showing that 'history matters in naturecultures' (p. 3); she evaluates several philosophies which dog lovers have defended, discussing different types of relations and intimacies, as well as suggesting alternatives to the discourse of animal rights; she takes us to the world of agility contests with their bad disguised distinctions of class, age, colour and gender (among owners) and of 
race and breed (among dogs); she introduces us into the breeding of puppies, its selection, genetic control and disciplining; she teaches us how to distinguish good from bad owners, able to invite their dog's trust and respect; she tells us stories of colonisation and conquest in which our four-leg companions unexpectedly appear as important actors; she informs us of the north-south colonial trade of abandoned dogs awaiting solidarity adoptions; she surprises us narrating the history of dog races and their multiple roles in the development of forms of human economy such as herding; and she entertains us with ambiguous descriptions of the (human)dog sexual world...

Donna Haraway leans on several authors' work. Some contributions are more circumstantial, and allow her to defend particular arguments; others, more basic, set up the theoretical framework (p. 610). Among the last, she acknowledges Alfred North Whitehead (prehention), Judith Butler (contingent foundation), Helen Verran (emergent ontologies), Charis (Cussins) Thompson (ontologic choreographies), Marilyn Strathern (partial connection) and, at another level, Louis Althusser (interpellation, p. 17). Rejecting as she usually does disciplinary borders, and looking for resources in diverse feminist studies, Haraway has resource to disciplines so various as paleobiology, archaeology, ecological developmental biology, population biology, history of science, environmental science, behavioural bioanthropology, etc., and puts to use interesting notions such as 'symbiogenesis' or 'multidirectional genetic flow'.

Haraway introduces these theoretical notes in a comprehensible way but without going too deep, offering succinct summaries of other illuminating researches that leave us wanting for more, and with little material to reach our own conclusions. Interesting references must be pursued and explored on one's own. Likewise, she does not enlarge on her points and, sometimes, gives important cues in just three lines easy to overlook, which forces us to an attentive reading (this is why here we give, when possible, the reference page where to trace arguments). However, we should not lose sight of the fact that this is a manifesto, a declaration of political intentions, and not a theoretical book. For the same reason, she assumes familiarity with some arguments and debates within feminist theory, through which she circulates fast, with ironic references and few words to the wise...

These are attractive canine stories which inform the multiple ways in which humans and dogs have entangled their histories and beings. But Haraway knows that, no matter how interesting they are, these narrations will not escape the continuous comparison to her previous work. The move from cyborgs to dogs is not easy -or, at least, not straightforward- and may require some explanation. Haraway herself seems to feel so, and instead of dodging the issue, accepts the challenge. She makes the relation between the two figures explicit from the beginning -actually from the very title-, clarifying what cyborgs and companion species have in common. To start with, both of them work against the imagination of purity and better protected species boundaries (p. 4). And, importantly, these two figures question important dichotomies crossing Western thought: human/non-human, organic/technological, carbon/silicon, freedom/structure, history/myth, rich/poor, state/subject, diversity/depletion, modernity/postmodernity, nature/culture. Dog stories illustrate this point, just as cyborgs had done it earlier: following the relationship human-canine at a developmental, historical, biographical level allows this critical work of partial connection.

Now, whilst this enumeration of similitudes between figurations aims at convincing us that this book is not a rupture with her previous work, it is also true that Haraway makes differences clear, in order to explain why she lets cyborgs rest and puts dogs to work. This new figuration is necessary, she claims, because companion species allow us to tackle different problems in a more effective way. In the eighties, Haraway's cyborg emerged in a world marked by Reagan's warfare and social politics, by the 
consequences of the Cold War in a 'non-optative post-nuclear world'; this figure, which inhabited ironically the contradictions of technoculture, enabled a critical perversion of the 'imperialist fantasies of technohumans' impregnating for years politics and research (p. 4). This context, however, has changed. Haraway suggests (p. 5) that nowadays, by the end of the millennium in the age of Bush Jr., new worries are added to the old ones -ecological concerns that need new conceptual tools to be deal with: debates about the sustainability of our forms of life and their impact on the environment, the unequal and unfair energy politics regulating access, distribution and exploitation of resources such as oil or water...

This change also affects our work with figurations. Both cyborgs and companion species should help us live critically our naturecultures, but they do it differently. This new figure, which actualises our concern for other species both at the level of a single individual and of populations, enables us to narrate stories not only of technoscience, but also of biopower and biosociality (p. 5). Moreover, a term like 'species' introduces into our discourse scientific resonance's -in particular of developmental biology-, and make us alert of the dangers of Aristotelian categorisations; it also reminds us of the corporeal nature of the semiotic, and of the hues of dirt to be found in everything counted or traded 'in species' (p. 15-6), since companion species inhabit impure, complex, finite and historical narratives (p. 16). With this manifesto, Haraway searches for a new figure that helps shape better politics and ontologies for the different forms of live that co-exist in these worlds of ours.

If the comparison between cyborgs and companion species ended here, perhaps we would not be very convinced of the need for this new figure. Just another way of challenging dichotomies? Is the dog just a repetition/mutation of the cyborg with ecological undertones -something like a four-leg barking furry cyborg? Will we find silicon under the dog skin? If that was the case, this book would be nothing else than an intellectual divertimento, and disenchantment would be justified. But if something is clear throughout the book is that, apart from being hybrid, Haraway's is a flesh-and-bone dog, whose carnality makes itself present in these hundred pages: it eats from our left-overs, gluttonously gulping down the processed liver delicatessen from our 'click-and-treat' reward dispenser; we pick up its dregs strolling around between pooper-scoopers through Donna's neighbourhood; we put up with its hair and breath in the sofa; its blood spills on the field when wolves attack it while protecting the herd; when on heat, we observe it negotiating instincts, hormones and reproductions with breeding associations; and, we have even acceded to an ambiguous exchange of fluids and favours on letting ourselves be caught by surprise by its deep-throat licks in more than one occasion.

Oh, my! This is more than some can take. The woman who had forced us to acknowledge our ontological intimacy with the non-organic -read computers, machines, prosthesis, chips, tools and any kind of artefacts- leaves in our hands, unexpectedly and without warning, a puppy of sharp canines that, mischievously, boasts of its new slogan 'run fast, bite hard' (p. 5). Differently put, this new figuration brings us to the organic -not simply to what exists, but to what lives, to what is alive. The same life beating through our planet crosses the pages written by this bio-feminist (because if Donna Haraway is a feminist, this book does not let us forget that she is also a biologist). The contrast between the living and the dead is so basic, that our difficulties in noticing the novelty of this book are quite telling... The consequences of this difference, however, are far-reaching, because, as Haraway tirelessly repeats, 'difference matters'. If this is so, then, what does this one matter? What does the companion species confronts us with, that didn't do the cyborg in its time?

To state it briefly: to a different type of responsibility towards life. This does not mean that we were not obliged towards our cyborg-kin; but this responsibility is different when we enter into relationship with a 
living being -an argument which Haraway started to develop with the coming on stage of the oncomouse. An animal and a person can have a relation in which they matter to each other; this is enough to make a difference in their lives, and we cannot ignore it. With this, we approach the strongest and the weakest point of the book. The strongest, because here the figure of the companion species shows at its best its differential role. Weakest, because this is where she runs the higher risk. For, as we will now see, she will claim that accepting our responsibility towards otherness compels us to consider seriously issues of respect, trust and love.

Haraway does not talk of species in general, but focuses, from the beginning, on the relationship doghuman. And she does not deceive herself; far from egalitarian, it is difficult to think of a relationship in which one part is more subordinated to the other in terms of physical dependence, disciplinary devices of control, punishment and rewarding. Violence continuously reappears in these dog stories. Then, how is it possible to talk of respect, trust and love in a relation constituted to such an extent by power, submission and authority? Here her feminist thought comes clearly to light (because if Donna Haraway is a biologist, this book does not let us forget that she is also a feminist). With a reasoning that might upset some, Haraway decides to abandon the fantasy of thinking love and respect from within equality, so as to understand the manifold situations in which these ideal conditions are never satisfied. The dog-people relation is of use to see how trust, respect and love can still emerge in situations configured by power and violence, but not exhausted by them. This is why Haraway suggests that 'dog writing' should be considered a contribution not only to technoscience, but also to feminist theory: "None of this work is about finding sweet and nice -"feminine"- worlds and knowledges free of the ravages and productivities of power. Rather, feminist inquiry is about understanding how things work, who is in the action, what might be possible, and how worldly actors might somehow be accountable to and love each other less violently" (p. 7).

In any case, recognising the inequality inherent within dog-human relationships leads us to reflect upon what to do with our own power-in-relation, forcing us to accept the impact that our existence has in their life. But not because we are all related, and damage to one species can revert negatively upon the rest (indeed, we cannot afford to forget that talking of life implies also death; Haraway does not insist in vain on the mortal character of the relationship). Rather, we must assume our responsibility in what Haraway, adopting Chris Cuomo's expression, calls 'the flourishing of otherness' ( $p .54)$, that is, to make what is necessary so that the other unfolds best its own possibilities of being -in the case at hand, that the dog be dog, in the best possible doggy conditions. In other words, to deal with life charges us with the responsibility to assume as our duty the other's well-being. Indeed, Haraway is not merely talking of life, but poses the ethical need -and this is her political proposal- to strive to turn this 'life' into 'living well together': "living well together with the host of species with whom human beings emerge on this planet at every scale of time, body, and space" (p. 25). This is an ethics of care-care for the other.

An ethics inspired by the flourishing of otherness starts by acknowledging that the other is not 'self'. This may sound like a platitude, especially when the other is a dog! And still, Haraway denounces two tendencies towards the denial of the other's otherness. The first, the conceptualisation of the other as a mere reflection of ourselves and our intentions -our creation. This idea is part of the fantasy of the man who realises itself through his creations, hiding the long history of mutual constitution (fantasy which Haraway alternatively calls 'humanist technophiliac narcissism' (p. 33) or 'dogsbody version of onanism' (p. 28)). According to this position, the servent dog, created through the skilful domestication of the free wolf, would be nothing but an instrument modelled by men and his culture (p. 27-8, 33). 
The second tendency to deny otherness is to humanise dogs, treating them as fury children (p. 37), and subjecting them to an economy of affects which often makes them more vulnerable (especially when fickling affects end up in abandonment).

To desire the other's wellbeing means not to impose 'self' and accept the other's radical otherness, admitting that, in a way, we live in different worlds, and that total comprehension is impossible. Nevertheless, this distance must never be an excuse not to try communication; on the contrary, 'communication across irreducible difference is what matters' (p. 49). It is a question of seeking to inhabit an inter-subjective world (p. 34), even if it is only approximately and precariously, built from within the materiality of the relation: ask in respect for all of time who and what are emerging in relationship, is the key. That is so for all true lovers, of whatever species' ( $p$. 50). This approach to otherness, based on 'negative knowledge' -knowing that you can only know what the other is not, a form of knowledge cultivated in theology (p. 50)- is what Haraway calls love.

This is a love that emerges from the relation, from the care, and puts us under the obligation of paying attention to 'all the fleshly detail of a mortal relationship' (p. 34), to these details which contribute to the optimal growth of those in relation, and whose neglect can damage both partners. Working for the relationship, 'striving to fulfill the messy conditions of being in love' (p. 35), includes thoughtful attentions. Like, for instance, learning how to play with dogs in such a way that they -and not only the owners- have fun (p. 45), or enjoy the satisfaction of common achievement and 'fulfillment of possibility' when taking up joint activities (p. 52). Or, more importantly, admitting that we often do not understand what the dog is, needs, wants or proposes. This ignorance compels us to a "permanent search for knowledge of the intimate other' (p. 35), to improve our relationship, recognising at the same time the multiple occasions in which we misunderstand each other and make mistakes. Only working for a relationship to the advantage of a common wellbeing can the other's respect and trust towards ourselves emerge. In a like manner, such a relationship brings about a reconceptualisation of property notions: if a person owns a dog, the latter also owns a person, which foregrounds reciprocity and mutual responsibility (p. 53-4).

On bringing forth a view on love that does not impose 'self', but opens up a space for the other to develop its otherness fully, Haraway comes close to the Heidegger of the humours, emotions and feelings -even though she will not like to hear it. Not only because they share a similar understanding of love, but also because both regard 'self-limitation' as an ethical practice that love demands. Indeed, in some cases the wellbeing of the other involves 'doing less' or 'doing differently', rather than 'doing more' -be it a voluntary restriction of one's action, one's power or one's being. Likewise, the key role of responsibility and love in our ecological futures brings Haraway closer to French philosopher Michel Serres, convinced of the power of love to mobilise the good in the world -the force that can save us. In both authors we can find the moderate optimism of those who believe that love can make a difference, and that our efforts can help create a better future. Thus, Haraway suggests that daily, ordinary acts may have political significance, and our more immediate environment offers plenty of occasions for theoretical reflection and ethical praxis. This book is, in her own words, 'a political act of hope' (p. 3).

Readers must not be confused, however. This book is not a return to a well-meaning humanism. The book may talk of love, but there is no slight sign of pseudo-refined affectation or of moral prescriptions. There are no teachings about unconditional love, which she rather considers a neurotic fantasy at best (p. 35) or, at worst, a dangerous discourse for the health of both pets and owners (p. 39). It should also be clear -since herein might lie part of the reluctance towards the book- that this work does not reintroduce the dichotomies organic-nonorganic or human-nonhuman. After her endeavours to 
deconstruct them, paying attention to the organic rooted in life may appear as a backward step. But deconstructing dichotomies does not mean ignoring differences; her reelaboration of 'biological kinship' problematises the 'organism' (p. 15), and deconstructs, from within the organic, the ontological borders between the human and the animal. Her insistence on the emergent relationship stops Haraway from falling into essentialism. If we must continuously ask ourselves what agency or entity emerges in our relationship with our dog, this always involves us -the agency of the self and of the other co-exist and co-constitute each other, and, therefore, differences are always already effects.

This book has disoriented many people in another sense. Some of its proposals and conclusions are so focused on 'dog land', that it is difficult to imagine what to do with this book if dogs are not one's direct interest. What's more, some voices (play with "Haraway + companion species" in Internet, and you'll see that these voices are quite a lot) complain that these reflections may fit dogs perfectly, but fail hopelessly with other animals, such as cats (cats are the favourite pets featuring in this criticism, even though I must confess that I have not been able to look at mine the same way after reading this book...). To be sure, the concrete conclusions about dogs cannot be directly extrapolated to cats -to cats or to parakeets or to the multitude of other species which have accompanied ours. If Haraway had sought to elaborate global conclusions valid for all companion species, this would be fierce criticism.

Nevertheless, the author warns from the beginning that the book is about dogs -in their diversity, but only about dogs, because dogs matter. Haraway states clearly that these beings are not an excuse to think something else: 'dogs are not to think with, but to live with' (p. 5). Difficult as it may be for some to understand, she is interested in dogs. This seeming limitation, I believe, is not so much a fault of the book as a wanted virtue; as if Haraway tried to perform practically her message: precisely because difference matters, we must think from within the specificity of the relationship, and not from categorical abstractions (p. 52). Not in vain is Haraway the scourge of analogy! For her, analogies obscure as much as they illuminate -sometimes a symptom of intellectual laziness, always a conceptual abuse. Dogs are dogs, cats are cats. Every companion species will need a particular, concrete analysis. In any case, it is not in spite of this concretion, but thanks to it, that the spirit of the book is generally valid and meaningful as a manifesto, since the question the book seeks to answer is "how might an ethics and politics committed to the flourishing of significant otherness be learned from taking dog-human relationships seriously?" (p. 3).

It might not be preposterous to think that the extreme concretion of this figuration is also a kind of strategic provocation: an answer to the excesses that the cyborg has suffered in the last years, becoming too often a model with which to think everything -too much. This time Haraway seems to want to hinder abuses; as she must well have known, the call of the dog does not work so well as a manifesto as the cyborg's did, and this imperfection reveals more clearly the need for specificity and the limits of any political aspiration. (Is this self-infliction of performative irony, putting things straight? Otherwise, why should repeat title the woman who took pains not to repeat herself, moving from cyborgs to dogs, even running the risk of staining her reputation so deservedly achieved?). I can almost imagine her smiling mockingly, waiting for the first daring people who, venturing to come to terms with their canine nature, proclaim that 'we are all dogs' -or, better still, bitches...

Perhaps I see too much into this book. Maybe, as Haraway herself sarcastically suggested, this work is nothing but the fantasy of a woman who loses lustre and falls back into the humano-sentimental temptations that she herself so boldly fought. Maybe there is no affectionate rebuke to some cyborgexcesses, the book appears weak theoretically and her ethic-political proposals before new problems 
of ecological sustainability sound too moralising. If this is so, I apologise for this recommendation -but honestly, I don't think so. If you still have not done so, read it. This is a pleasant and entertaining book, reasonably easy if readers are familiar with the Haraway writing, that coins new expressions, condenses adjectives and plays with the syntax for the sake of expression, theoretical accuracy and humour. Distancing itself from academic tones, the text offers some lyrical moments, many more provocative. (There is certainly something daring in having such a scholar defending the goodness of authority and of some behaviourist rewarding systems on behalf of responsibility, freedom and love for the other's possibilities of being (p. 44-7)).

I won't try to convince potential readers that this book is as transgressive and suggesting as the Cyborg Manifesto -in some respects it is not, in others maybe more. In any case, it deserves to be read not against the background of what we expect it to say, but opening ourselves to what it actually says, letting it develop its own possibilities of being, without fast formulae or diagonal readings. In these hundred pages there is more, quite a lot more, than what the first disorientation may let us think. To find this plus, and see how it can make a difference in our lives and works is the pending task that this book entrusts us. In any case, whether we like it or not, there is no denying that this work is an act of (personal) courage and of (professional) love. Or is it the other way round? Well, with Donna, it doesn't really matter...

\section{Formato de citación}

Pallí, Cristina. (2006). Difference that matter: On love in the kennel of life. Athenea Digital, 10, 250258. Disponible en http://antalya.uab.es/athenea/num10/palliM.pdf.

\section{(9)}

Este texto está protegido por una licencia Creative Commons.

Usted es libre de copiar, distribuir y comunicar públicamente la obra bajo las siguientes condiciones:

Reconocimiento: Debe reconocer y citar al autor original.

No comercial. No puede utilizar esta obra para fines comerciales.

Sin obras derivadas. No se puede alterar, transformar, o generar una obra derivada a partir de esta obra.

$\underline{\text { Resumen de licencia }}$

$\underline{\text { Texto completo de la licencia }}$ 